\title{
Merkezi Yönetim Cari Transfer Harcamalarının Mali Büyüklüğünün Değerlendirilmesi
}

\author{
Assessment of Financial Size of Central Government Current Transfer Expenditures
}

\section{Özhan ÇETINKAYA}

Prof. Dr., Uludağ Üniversitesi, İ̈BF,

Maliye Bölümü, ozhanc@uludag.edu.tr

https://orcid.org/0000-0002-8729-611X

\section{Mehmet Fatih ASLANTAŞ}

Doktorant, Uludă̆ Üniversitesi, SBE,

Maliye A.B.D., mfaslantas@gmail.com

https://orcid.org/0000-0002-5987-2976
Makale Başvuru Tarihi / Received: 12.03.2019

Makale Kabul Tarihi / Accepted: 01.05.2019

Makale Türü / Article Type: Araştırma Makalesi

\section{Anahtar \\ Kelimeler: \\ Bütçe, \\ Кати \\ Harcamalarl \\ Tasnifi, \\ Cari Transfer \\ Harcamalarl,}

Keywords:

Budget,

Public Expenditure Classification,

Current Transfer Expenditures,

\section{ÖZET}

Merkezi yönetim bütçesinden yapılan harcamaların türlerinin ve büyüklüklerinin belirlenmesi, harcamaların ekonomi üzerinde yaratacă̆ yapılması kaynakların etkin kullanımının belirlenmesinde hem idari, hem siyasi hem de iktisadi açıdan yapılacak analizler için gerekmektedir. Bütçe belgesinden sorumlu olan yürütme organının ve politika yapıcılarının seçmenlere hesap vermek temelinde, yönettikleri kurumların nereye ne kadar harcama yaptıklarını, hangi hizmetlerin ne maliyetle sunulduklarını ve yapılan harcamanın ekonomik etkilerini bilmek ve bildirmek zorunlulukları vardır. Çalışmada, ilk olarak, kamu harcamalarının tasnifi üzerinde durularak inceleme konusunu oluşturan "cari transfer harcamalarının" kavramsal içeriği hakkında açıklamalar yapılmıştır. Kavramsal açıklama sonrasinda bu harcamaların 2006 yılından günümüze rakamsal büyüklüklerinin enflasyon, seçimler ve büyüme rakamları ile ilişkisine bakılmıştır. Ikkinci olarak, "sermaye birikimi hedeflemeyen ve cari nitelikli mal ve hizmet alımını finanse etmek amacıyla yapılan karşılıksız ödemeler" şeklinde tanımlaması yapılan bu harcamaların cumhurbaşkanlığı ve milletvekili seçim yılı olan 2018 yılı özelinde daha alt harcama kalemleri temelinde incelemesi ve değerlendirmesi yapılmıştır. 


\section{GİRIŞ}

Merkezi yönetim bütçesi ile yapılan harcamaların toplam büyüklüğü mali ve iktisadi olarak ne kadar önemliyse harcamaların türleri ve büyüklükleri de onun kadar önemlidir. Türkiye'de bütçe harcamaları "analitik bütçe sınıflandırması" ile çeşitli türlerde belirtilmektedir. Sınıflandırmaya göre harcamalar; kurumsal, fonksiyonel ve ekonomik yönden ele alınmaktadır. Çalışmanın konusu olarak ele alınan cari transferler, "ekonomik sınıflandırma" içinde yer almakta olup bu sınıflandırma, harcamanın ekonomi üzerindeki etkisini inceleyen bir sinıflandırma olarak kullanılmaktadır. Ekonomik sinıflandırmayı; cari harcamalar, yatırım harcamaları ve transfer harcamaları oluşturmaktadır. Bu sınıflandırma Türkiye'de 1964 yılından sonraki bütçe hazırlık şeklinde net olarak yer almaya başlamıştır (Sayar, 1954:111). Klasik bütçe anlayışının önemli ayrıntılarından biri olan ekonomik sınıflandırma, özellikle ekonomik anlamda geleceğe etkisinin fazla olduğu bilinen yatırım harcamalarının yanında cari dönemde etkisinin olduğu bilinen cari ve transfer harcamalarının da ne kadar olduğunun bilinmesi açısından önemlidir. Ekonomik sınıflandırma günümüz itibariyle analitik sınıflandırma yapısı içinde önemle kullanılan bir sınıflandırma olarak varlığını devam ettirmektedir. Maliye politikası aracı olarak kullanılan kamu harcamalarının, türlerine bağlı olarak azaltılması ya da artırılmasının çarpan etkisi ile ekonomi üzerinde daraltıcı ya da genişletici bir etki doğurduğu bilinen bir gerçektir. Ekonomik sınıflandırma yoluyla günümüzde gerek yatırım harcamalarının gerekse cari ve transfer harcamalarının büyüklüğ̈̈nün bilinmesi makroekonomik büyüklüklerin (büyüme, enflasyon, işsizlik, cari açık gibi) ne yönde gelişme göstereceğine dair politika yapıcılara işaret verme de yardımcı olmaktadır. Bu kapsamda cari transfer harcamalarının da durumunu görmenin bu yönde fayda sağlayacağı düşüncesindeyiz. Dolayısıyla bu harcamaların analitik sınıflandırma içinde yer almaya başladığı 2006 yılından sonraki rakamsal incelemeler yapılarak bu harcamaların yıllara yaygın durumunu incelemek çalışmanın bir kısmını oluştururken, Türkiye ekonomisinde enflasyon, büyüme, faiz oranları ve işsizlik yönüyle önemli gelişmelerin yaşandığı ve aynı zamanda Cumhurbaşkanlığı seçiminin yapıldığ 2018 yılının iktisadi, mali ve siyasi açıdan önemli bir yıl haline geldiğini, bu yıla ait harcamaların da incelenerek durum tespiti yapılmasının çalışmanın diğer kısmını oluşturduğunu belirtmek gerekir. Kamu harcamalarının enflasyon ve büyüme gibi önemli iki makro değişkeni etkileyebilen maliye politikası aracı olduğu dikkate alındığında "cari transfer harcamalarındaki” değişikliğin boyutu, makro değiş̧kenlerin aşağı ya da yukarı yöne doğru akışını ya da değişmeyen durumunu görmek açısından önemli hale gelmektedir.

Türkiye'de Hazine ve Maliye Bakanlığının yayımladığı verilerde ekonomik sınıflandırma kapsamındaki cari harcamalar ile transfer harcamalarının ayrı belirtilmesinin yanında "cari transferler" olarak birleşik kavram şeklinde kullanımının olduğu da görülmektedir (https://www.muhasebat.gov.tr/content/genel-yonetim-maliistatistik-detayi?tabId=1\&pageId=2). "Cari transferler" kavramının literatürdeki yerine bakıldığında ise bu şekildeki bir kullanımının olmadı̆̆ı, transfer harcamaları içinde cari yönü olanlar şeklinde belirtildiği görülmüştür (Feyzioğlu, 1965:183). Kavramın Türkiye'de analitik bütçe sınıflandırması ile uygulamada yer alması, açıklanmasına olan ihtiyacı doğurduğu gibi önceki paragrafta belirtildiği üzere bu harcamaların boyutunun dikkat çekecek düzeyde olması yıllara yaygın analizinin yapılması gerektiği düşüncesini geliştirmiştir. Buradan hareketle çalışmanın harcamaların mali büyüklüğünün değerlendirilmesi kısmından önce kamu harcamalarının kuramsal olarak tasnifi, içerikleri ve cari transfer harcaması kavramının kamu harcamaları içindeki kavramsal açıklamasının yapılması yerinde olacaktır.

\section{KAMU HARCAMALARININ TASNIFI VE ICÇERIĞİ}

Maliye biliminde yaşanan gelişmeler, maliyenin sadece mali açıdan kamunun gelir ve giderlerinin dengelenmesini ele alan bir bilim anlayışından ibaret olmadığını, aynı zamanda toplanan gelirlerin ve yapılan harcamaların toplumun da içinde yer aldığı ekonomiye ne yönde etki ettiğinin de incelemesini yapan bir bilim dalı olduğunu ortaya koymuştur. Diğer bir deyişle maliyenin mali ve iktisadi yönleriyle bir bütünü oluşturduğu görülmüştür. Bu kapsamda yapılan harcamaların kayıt ve tasnif şeklinin harcamanın ekonomi üzerindeki etkilerini görmede önem kazanması kaçınılmaz olmuştur. Harcamaların tasnifinde geçmiş dönemlerde harcamayı yapan idarelerin üzerinden kayıt tutma (kurumsal tasnif) söz konusuyken zamanla harcamanın ekonomi üzerindeki etkileri dikkate alınmak üzere bir kayıt tutma (ekonomik tasnif) geliştirilmiş, bunu takiben yirminci yüzyılın sonu itibariyle hizmet türleri itibariyle kayıt tutma (fonksiyonel tasnif) tasnif türlerine eklenmiştir. Böylece kamu harcamalarının çeşitli yönlerden tasnifleri ile bütçe belgesi ile politika oluşturma yönünde analizler yapılarak, karar alıcılara yol göstermek amaç edinilmiştir (Erginay, 1981:152). Günümüzde 
birçok ülkede ve Türkiye'de uygulanan tasnif şekilleri "analitik sınıflandırma" altında gösterilmiş olup, bütçe formları ve kayıt belgeleri vasıtasıyla harcamanın üzerinden veri üretebilme imkânına ulaşılmıştır.

\subsection{Ekonomik Yönüyle Harcamaların Tasnifi}

Ekonomik yönüyle harcamaların tasnifi, yapılan harcamanın ekonomi ve sosyal hayat üzerindeki etkilerini görmek amacıyla düşünülmüştür. Diğer bir deyişle bu tasnif, bütçe ile gerçekleştirilen harcamanın cari dönemdeki ya da gelecek dönemdeki ekonomiyi ve sosyal yaşamı makro büyüklükler yönüyle (enflasyon, büyüme, gelir dağılımı) ne kadar etkiliyor ya da etkileyecek, bunu anlama ve görme imkânı sağlayacak bir tasnif türüdür. Ekonomik tasnif kapsamında harcamalar öncelikle reel (gerçek) ve transfer harcamaları şeklinde iki türe ayrılmakta, sonrasında reel harcamalar da cari ve yatırım harcamaları olarak ikiye ayrılmaktadır. Kamu harcamalarının tasnifi konusunda çeşitli tasnif türleri içinde temel ayrımın reel harcamalar ve transfer harcamaları şeklinde yapılan ikili tasnif olduğu literatürde kabul görmüş̧ür (Batırel, 1979:105). Bu ikili ayrım kapsamında reel harcamaların da cari ve yatırım harcamaları olarak ikiye ayrılmasının, harcamaların çeşitli yönlerden değerlendirilmesi açısından yapıldığını da belirtmek gerekir. Dolayısıyla kamu harcamalarını cari, yatırım ve transfer harcamaları şeklinde üçlü bir ayrıma (ekonomik tasnif) tabi tutarak harcamaların durumunu değerlendirmek, harcamalardan beklenilen faydaların dönemselliğini görmek açısından yerinde olmaktadır. Türkiye'de 1964 yılı bütçesinde kullanılmaya başlanan üçlü ayrım şekline, 2006 yılında uygulanmaya giren performans bütçe ile analitik sınıflandırma kapsamında da devam edilmiştir.

Ekonomik tasnif kapsamında; reel harcamalar, kamu hizmetlerinin sunulmasında kullanılan iktisadi malları veya üretim faktörlerini satın almaya yönelik harcamalardır (Gürsoy, 1975:130). Bu harcama ayrımını ilk kullanan İngiliz Prof. Pigou iken daha sonra açıklık getiren Amerikalı Prof. Due olmuştur (Gürsoy, 1975:130). Bu iki bilim adamı harcamaların ekonomik etkilerinin söz konusu olduğunu, iktisadi mal alımı ya da üretim faktörü alımının gerçek olarak kabul edilip karşılıklı olduklarını, diğer harcamaların ise böyle bir alım içinde olmadıklarını karşılıksız olarak yapıldıkları için devletten karşı tarafa transfer olarak yapıldıklarını belirtmişlerdir. Benzer şekilde Fransız maliyeci M. Duverger de harcamaları karşılıklı ve karşılıksız giderler olarak adlandırmıştır (Duverger, 1955:22).

Reel harcamalar, cari ve yatırım harcamaları olarak ikiye ayrıldığında cari harcamalar; etkisi(faydası) cari dönemde hissedilen harcamalar iken yatırım harcamaları; etkisi gelecek dönemleri kapsayan harcamalardır. Devletin cari dönem içinde yaptığı harcamalar; bazen işgücü için ödediği personel giderleri, bazen kurumların günlük ihtiyaçları olan elektrik, gaz, su, bazen de kırtasiye, bakım-onarım giderleri olabilmektedir. Bu harcamalar genellikle faydası bir yıl içinde bir ya da birkaç kez kullanmakla tükenen (dayanıksız) mallar için her yıl yapılan harcamalardır (Edizdoğan vd., 2018:88). Devletin gelecek dönemi kapsayan harcamaları ise; sermaye malı alımına yönelik yaptı̆̆ı harcamalar olup; baraj, yol, kamu binaları, makine-araç, büyük onarım gibi harcamalarıdır. Bu harcamalar üretimi artıran, birden fazla kullanılıp tükenmeyen, üretim faktörlerinin verimliliğini artıran, faydası birden fazla yılı kapsayan harcamalardır.

Transfer harcamaları, devletin karşılığı olmadan yaptığı, diğer deyişle karşılık olarak mal, hizmet ya da üretim faktörü satın almadan yaptığı harcamalardır. Devletin yaptığı iş, vergi yolu ile belli kesimden topladığı gelirleri karşı1ıksız olarak belli kesime aktarmasından ibarettir (Batırel, 1979:106). Devlet bu aktarımı iktisadi, mali ve sosyal transferler şeklinde çeşitli konularda yapmaktadır. Transfer harcamasının harcamanın yapıldığı zaman dilimi içinde milli gelirde değişiklik oluşturması söz konusu değildir. Harcamanın yapıldığı idare, kuruluş ya da insanlar için gelir olan bu miktarın onlar tarafından tüketim harcamalarında kullanılmaları halinde milli gelire dâhil olacaktır (Edizdoğan vd., 2018:91). Transfer harcamalarına verilebilecek örnekler; işsizlere, fakir öğrencilere, düşük gelirlilere ödenen tutarlar, kamu borç faizleri, vergi iadeleri, iktisadi amaçlı üreticilere verilen yardımlar, devletin mahalli idarelere yaptığı yardımlardır. Bu harcamaların iktisadi, mali, sosyal türleri itibariyle ekonomi üzerindeki etkileri farklıdır. Kişilerin gelirlerini artıran transfer yardımları ekonomide alım gücünün artması ile hareket sağlayacaktır. Bununla birlikte üreticiye yapılacak transferler de üretimin artmasını sağlayarak ekonomiyi harekete geçirecektir. Transfer harcamalarının yapıldığı kesimin durumuna göre değişen etkileri (Erginay, 1983:154) olsa da amaç gerek üretici gerekse tüketici refahını artırarak ekonomiyi harekete geçirmektir. 


\subsection{Kurumsal Yönüyle Harcamaların Tasnifi}

Kurumsal yönüyle harcamaların tasnifi, devlet örgütünü oluşturan kurum ve kuruluşların kendilerine görev olarak verilen hizmetler için yaptıkları harcamaları kayıt altına almayı ele alan sınıflandırmadır. Diğer bir deyişle, kamu harcamalarını harcamayı yapan idareye göre ayıran bir tasniftir (Erginay, 1981:152). Bu tasnifin kullanılmasındaki amaç, hükümet ve idari birim açısından siyasi, idari ve mali sorumlulukların durumunun anlaşılması (Susam, 2016:180) ve sektörün (eğitim gibi) işleyişini yöneten birimin (Eğitim Bakanlığı gibi) o hizmeti yönetmede kullandığı kaynakların kamuoyu tarafından görülmesinin sağlanmasıdır. Diğer bir deyişle ilgili hizmeti yürütmekle sorumlu olan kişinin (bakan) harcadığı kaynağın hesabını yasama organına vermesi ve durumunun değerlendirilmesi mümkün olmaktadır. Daha geniş olarak bakıldığında ise bu sınıflandırma ile devlet örgütünün işleyişinde yasama, yürütme ve yargı organlarının hizmet maliyetleri belirlemiş olacak, bu şekliyle maliyetlerin değerlendirilmesi için analiz imkânı elde edilmiş olacaktır.

\subsection{Fonksiyonel Yönüyle Harcamaların Tasnifi}

Devletin ekonomi üzerindeki artan rol ve fonksiyonları klasik maliyenin idari-kurumsal tasnif şeklinin yetersiz kalmasına yol açması ile modern maliyenin getirdiği ve milli gelir üzerinde devletin etkisinin de gösterilmesini içeren iktisadi ve fonksiyonel tasnif şekli uygulaması geliştirilmiştir (Feyzioğlu, 1976:177). Fonksiyonel yönüyle harcamaların tasnifi, devletin yaptığı harcamaların yapılan "işin" (hizmet) türüne göre kayıt altına alınmasıdır. Bu tasnifte harcamayı yapan idarelerin her birinin hangi işe harcamayı yaptıysa kayıtlarını o işle ilgili göstermesi, birden fazla idarenin o işe harcadıklarının toplanarak devletin o işe (hizmet) ne kadar harcama yaptığının tespit edilmesi, hizmetin maliyetinin belirlenmesi ve böylece hizmete yapılan harcamanın daha etkin yapılması (Erginay, 1981:156) yollarının araştırılması amaçlanmıştır. Bu tasnif şekline 1913-1915 yılları arasında $\mathrm{ABD}$ 'de mahalli idarelerde performans bütçe anlayışının tartışılmaya başladığı dönemde uygulanmaya başlanmış (Falay, 1987:39), sonrasında merkezi idarenin bütçe hazırlığında bütçe teknikleri kapsamında kullanılmıştır. Türkiye'de uygulanan performans esaslı bütçe sisteminde harcamaların tasnifinde kullanılan fonksiyonlar; eğitim, sağlık, sosyal güvenlik, savunma, kamu güvenliği, çevre, ekonomik, toplum refahı, genel hizmetler şeklinde belirlenmiştir. Kurumların bu tasnife göre harcamalarını ilgili fonksiyona kayıt etmeleriyle bütçeden yapılan her fonksiyonun maliyetini tespit etme imkânı oluşmaktadır.

\section{CARİ TRANSFER HARCAMASI KAVRAMI VE MALİ BÜYÜKLÜĞÜNE BAKIŞ}

Cari transfer harcaması kavramı kullanılırken hangi harcamaların bu türün içine gireceği konusunda akıllarda soru işareti kalmaktadır. Türkiye'de 2006 yılından önce kullanılan harcama sınıflandırmasında yer almayan bu kavramın içeriğinin açıklanması ve sonrasında harcamalar içindeki yerinin görülmesi harcama analizleri ve değerlendirmeleri yapmak açısından önemlidir.

\subsection{Cari Transfer Harcaması Kavramı}

Harcamaların tasnif türleri içinde daha öncede ifade edildiği üzere çalışmanın üzerinde durduğu tasnif şekli ekonomik tasniftir. Ekonomik tasnifin dişındaki diğer tasnif türleri de harcamalarla ilgili yapılan çalışmaların içeriğine göre araştırmacılar tarafından tercih edilerek kullanılmaktadır. Cari transfer harcamalarının bütçe içindeki büyüklüğünü ele alan çalışmamızın analiz kısmından önce bu kavramın literatür boyutu ile durumunu belirtmek önemlidir. Ekonomik sınıflandırma kapsamında önceki başlıkta da değinildiği üzere harcamalar, önce gerçek ve transfer harcamaları şeklinde ayrılmış olup gerçek harcamalar da cari ve yatırım harcamaları olarak ayrılmıştır. Ekonomik sınıflandırmayı geniş yönlü düşündügümüzde harcamaların literatürde cari, yatırım ve transfer harcamaları şeklinde tasnif edildiği, "cari transfer" şeklindeki harcama kavramının geçmişte tam bu şekilde olmasa da "transferlerin cari dönem için yapılanları" şeklinde ifade edildiği bilinmektedir (Feyzioğlu, 1965:184). Harcamalarla ilgili yapılan açıklamalarda da belirtildiği üzere cari harcamalar karşı1lıkı, transfer harcamaları karşılıksız yapılan harcamalardır. Yine cari harcamalar milli gelirde değişiklik oluşturan, transfer harcamaları ise milli gelirde değişiklik oluşturmayan harcamalardır. Dolayısıyla bu iki harcama türünün "cari transferler" adıyla bir araya getirilmesi tabir yerindeyse "deve kuşu" isminin kullanılması gibi olsa da anlatılmak istenilen konu nettir. Konu; transferlerin cari dönemi kapsayanlarıdır. Hazine ve Maliye Bakanlığının verilerine bakıldığında (https://www.muhasebat.gov.tr/content/genel-yonetim-mali-istatistikdetayi?tabId=1\&pageId=2) harcamaların "faiz hariç harcamalar" ve "faiz harcamaları" şeklinde bir tasnif 
içinde gösterildiği "faiz hariç harcamaları"” ise personel giderleri, SGK'ya devlet primi giderleri, mal ve hizmet alım giderleri, cari transferler, sermaye giderleri, sermaye transferleri, borç verme ve yedek ödenekler şeklinde alt başlıklarda ele alındığı görülmüştür. Literatürdeki harcama tasniflerinden yola çıkarak bütçe hesaplarında ve Hazine ve Maliye Bakanlığının yayımladığı verilerde kullanılan cari transferler kavramının, "cari yıl içinde kullanıma sunulan, faydası bir yıl içinde tüketilen ve karşıllğı olmayan harcamalar" olarak tanımlamak mümkündür. Analitik bütçe sınıflandırmasına ilişkin rehberlerde ve bütçe hazırlık rehberlerinde ${ }^{1}$ bu kavramın tanımı ise; "Sermaye birikimi hedeflemeyen ve cari nitelikli mal ve hizmet alımını finanse etmek amactyla yapılan karşılıksız ödemelerdir" şeklinde yapılmıştır. Ancak yayımlanan verilerde yer alan "sermaye transferlerine" de bakıldığında onların da cari yıl içinde yapılan ve karşılıksız oldukları görülen harcamalar olduğunu da belirtmek gerekir.

"Cari transferler" adlı harcama kalemi ile ilgili olarak "Analitik Bütçe Sınıflandırmasına İlişkin Rehber" de detaylı açıklamalar yapılmıştır. Buna göre cari transfer başlığı altında; kamu teşebbüslerine, sosyal güvenlik kurumlarına, döner sermayeli işletmelere, fonlara ve diğer teşekküllere yapılan "görev zararları", genel yönetim kapsamında yer alan kurum ve idarelere yapılan "hazine yardımlarl", derneklere, vakıf üniversitelerine, siyasi partilere, memurlara öğle yemeği, sosyal amaçlı fonlara, seçim giderleri için partilere yapılan " $k a r$ amacl gütmeyen kuruluşlara yapılan transferler", burslar ve harçlıklar, eğitim amaçlı, sağlık amaçl1, yiyecek amaçl1, tarımsal amaçlı, sosyal amaçlı, ekonomik ve mali amaçlı "hane halkına yapılan transferler", fark ödemesi destekleme hizmetleri, hayvancılık destekleme hizmetleri, kırsal kalkınma amaçlı tarımsal destekler, tarım sigortası destekleme hizmetleri şeklindeki "tarımsal destekleme ödemeleri”, çocuk esirgeme kurumuna yardım, muhtaçlara aylık ödemesi kapsamındaki "sosyal amaçlı transferler", Kıbrıs'a ve uluslararası kuruluşlara yapılan "yurtdışına yapılan transferler", vergi gelirlerinden yerel yönetimlere yapılan ödemeler, savunma sanayii fonuna ve sosyal yardımlaşma fonuna yapılan ödemelerin yer aldığı "merkezi idare gelirlerinden ayrılan paylar" bulunmaktadır. Cari transfer harcaması kavramı hakkında daha önceki kısımda da belirtildiği üzere söylenebilecek söz, 2006 yılından itibaren analitik bütçe sınıflandırması altındaki kullanımı cari transfer harcamaları olarak yapılan bu harcamaların geçmişte de devlet bütçesi içinde gösterildiği, 1940'lar da transfer harcamalarının bir kısmının cari hesaplarda bir kısmının sermaye hesaplarında gösterilmesine yönelik tartışmalar (Feyzioğlu, 1975:184) yaşandığı ve ilerleyen yıllarda ise cari hesaplarda gösterilen transfer harcamalarının bugünkü şeklinin belirlendiğidir. Dolayısıyla günümüzdeki cari transfer harcaması sınıflandırması altında yer alan harcamaların büyük çoğunluğunun geçmişte yaşanan sınıflandırma tartışmalarının neticesinde belirlendiği ve bugünkü şekline ulaştı̆̆ını söylemek gerekir.

\subsection{Cari Transfer Harcamalarının Büyüklüğü ve Makro Büyüklüklerle Birlikte İncelenmesi}

Çalışmanın giriş kısmında da belirtildiği üzere ilk inceleme ve değerlendirmemiz; genel anlamda cari transfer harcamalarının 2006 yılı sonrasındaki gelişimi ile ilgilidir. Cari transfer harcamalarının mali büyüklügünü görmek ve bazı değerlendirmeler yapmak için analitik sınıflandırmada 2006 yılından itibaren kullanılan veriler dikkate alınarak bu harcamaların yıllara yaygın gelişimlerinin gösterildiği Tablo 1 ve bu harcamalarda yaşanan artış ile seçimler ve enflasyon oranlarının gösterildiği Tablo 2 birlikte analiz edildiğinde görünen bazı durumlar vardır. İlk durum; gerçekleşen harcama rakamlarının 2010-2014 yılları arasında yapılan tahminlerden az olduğu, diğer y1llarda ise tahminlerden (Tablo 1) fazla olduğudur. İkinci durum, harcamaların yıllara göre artış oranlarına bakıldığında (Tablo 2), her y1l artışın gerçekleştiği, gerçekleşen artışların enflasyon oranları ile karşılaştırması yapıldığında (2011 yılı hariç) enflasyonun çok üzerinde artışın olduğu, dolayısıyla harcamaların görünürde değil gerçek artış şeklinde geliştiğidir. Üçüncü durum, seçim yılları yönüyle rakamlardaki artışa bakıldığında; 2007 ve 2009 yılları artışının sırasıyla \%27 ve \%30,7 ile rekor kırdığg, 2017 ve 2018 yıllarındaki artışı \%20 dolayında olduğu, 2014 ve 2015 yıllarında seçim olmasına rağmen diğer seçim yılları kadar artışın olmadığı 2016 yılında seçim olmasa da artışın \%23 gibi yüksek bir oranda olduğu görülmektedir.

1 http://www.bumko.gov.tr/Eklenti/11265,01-2018-10-8taslak-rehber-aciklamalar2019-2021pdf.pdf?0 
Tablo 1. Cari Transfer Harcamalarının Gelişimi (2006-2017)

\begin{tabular}{|c|c|c|c|c|c|c|c|c|c|c|c|c|}
\hline TAHMIN & 2006 & 2007 & 2008 & 2009 & 2010 & 2011 & 2012 & 2013 & 2014 & 2015 & 2016 & 2017 \\
\hline Cari Transferler & 49.107 & 60.862 & 69.206 & 87.955 & 102.172 & 115.778 & 130.220 & 151.287 & 163.553 & 176.424 & 217.673 & 249.265 \\
\hline -Görev Zararları & 5.318 & 6.961 & 9.778 & 16.125 & 17.284 & 20.594 & 25.687 & 25.970 & 29.463 & 32.279 & 52.407 & 54.821 \\
\hline -Hazine Yardımları & 22.074 & 28.764 & 31.684 & 37.456 & 49.369 & 52.927 & 54.752 & 59.518 & 58.083 & 58.899 & 64.113 & 80.213 \\
\hline $\begin{array}{l}\text {-Kar Amacı } \\
\text { Gütmeyen } \\
\text { Kuruluşlara } \\
\text { Yapılan } \\
\text { Transferler }\end{array}$ & 178 & 662 & 335 & 831 & 726 & 893 & 614 & 1.701 & 2.012 & 1.994 & 2.068 & 2.489 \\
\hline $\begin{array}{l}\text {-Hane Halkına } \\
\text { Yapılan } \\
\text { Transferler }\end{array}$ & 6.804 & 6.880 & 7.362 & 7.965 & 9.855 & 11.487 & 13.869 & 21.874 & 25.070 & 26.930 & 33.554 & 38.950 \\
\hline $\begin{array}{l}\text {-Yurtdışına } \\
\text { Yapılan } \\
\text { Transferler }\end{array}$ & 567 & 636 & 654 & 847 & 1.028 & 1.212 & 1.420 & 1.491 & 1.743 & 1.920 & 2.550 & 2.754 \\
\hline $\begin{array}{l}\text {-Gelirden Ayrilan } \\
\text { Paylar }\end{array}$ & 14.164 & 16.957 & 19.391 & 24.729 & 23.908 & 28.662 & 33.875 & 40.731 & 47.179 & 54.400 & 62.980 & 70.036 \\
\hline GERÇEKLEŞEN & 2006 & 2007 & 2008 & 2009 & 2010 & 2011 & 2012 & 2013 & 2014 & 2015 & 2016 & 2017 \\
\hline Cari Transferler & 49.851 & 63.291 & 70.360 & 91.975 & 101.857 & 110.498 & 129.477 & 148.742 & 162.282 & 182.786 & 224.847 & 270.962 \\
\hline -Görev Zararları & 7.245 & 8.641 & 9.606 & 16.489 & 16.467 & 20.071 & 22.062 & 28.243 & 29.618 & 34.843 & 46.779 & 63.882 \\
\hline -Hazine Yardımları & 21.738 & 29.033 & 31.203 & 44.599 & 47.152 & 44.020 & 52.027 & 55.059 & 57.738 & 57.532 & 75.783 & 86.989 \\
\hline $\begin{array}{l}\text {-Kar Amacı } \\
\text { Gütmeyen } \\
\text { Kuruluşlara } \\
\text { Yapılan } \\
\text { Transferler }\end{array}$ & 185 & 681 & 443 & 844 & 1.083 & 1.392 & 926 & 1.786 & 2.552 & 3.688 & 2.465 & 3.400 \\
\hline $\begin{array}{l}\text {-Hane Halkına } \\
\text { Yapılan } \\
\text { Transferler }\end{array}$ & 5.916 & 7.236 & 8.235 & 7.828 & 9.875 & 12.821 & 18.784 & 22.161 & 23.522 & 29.047 & 34.970 & 41.397 \\
\hline $\begin{array}{l}\text {-Yurtdışına } \\
\text { Yapılan } \\
\text { Transferler }\end{array}$ & 620 & 506 & 615 & 721 & 968 & 1.150 & 1.296 & 1.623 & 1.566 & 1.909 & 2.238 & 2.618 \\
\hline $\begin{array}{l}\text {-Gelirden Ayrilan } \\
\text { Paylar }\end{array}$ & 14.145 & 17.192 & 20.256 & 21.491 & 26.308 & 31.042 & 34.379 & 39.868 & 47.283 & 55.765 & 62.609 & 72.672 \\
\hline
\end{tabular}

Kaynak: Hazine ve Maliye Bakanlığı

Tablo 2. Cari Transfer Harcamalarının Yıllık Artışı, Enflasyon Rakamları ve Seçim Yılları (2007-2018)

\begin{tabular}{|c|c|c|c|c|c|c|c|c|c|c|c|c|}
\hline Yillar & 2007 & 2008 & 2009 & 2010 & 2011 & 2012 & 2013 & 2014 & 2015 & 2016 & 2017 & 2018 \\
\hline Harcama Artı̧ı & 27,00 & 11,20 & 30,70 & 10,70 & 8,50 & 17,20 & 14,90 & 9,10 & 12,60 & 23,00 & 20,50 & 19,30 \\
\hline \begin{tabular}{|l} 
Enflasyon \\
Rakamları
\end{tabular} & 8,39 & 10,06 & 6,53 & 6,40 & 10,45 & 6,16 & 7,40 & 8,17 & 8,81 & 8,53 & 11,92 & 20,30 \\
\hline Büyüme & 5,0 & 0,8 & $-4,7$ & 8,5 & 11,1 & 4,8 & 8,5 & 5,2 & 6,1 & 3,2 & 7,4 & $3,8^{*}$ \\
\hline Seçimler & 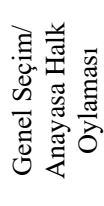 & & 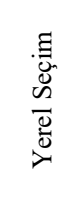 & 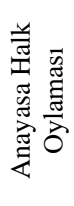 & 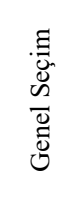 & & & 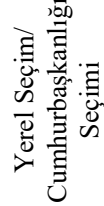 &  & & 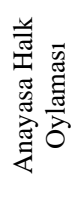 & 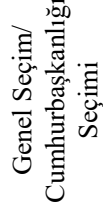 \\
\hline
\end{tabular}

Kaynak: Enflasyon ve büyüme rakamları için www.tuik.gov.tr den yararlanılırken harcama artışları gerçekleşen rakamlarıyla Tablo 1'den tarafımızca hesaplanmıştır. 2008 yılı kriz yılıdır. Enflasyon rakamları TÜFE'dir. *Tahmin

Çalışmanın diğer kısmını oluşturan inceleme ve değerlendirmemiz 2018 yılı ile ilgilidir. Türkiye'de iktisadi ve siyasi yaşanmışlık açısından önemli bir yıl olan 2018 yılı verileri ile birlikte bir önceki yıl verileri üzerinden gidilerek cari transferlerin Tablo 3'e göre gerçekleşen kümülatif rakamlarına bakıldığında, bu harcamaların 
2017'den 2018'e \%19,3 arttığ1, bu y1llara ait merkezi yönetim bütçesinin artış oranının ise \%22,4² olduğu anlaşılmıştır. Bu rakamlara göre 2017-2018 dönemi için bu harcamaların artışıınn kümülatif bütçe artışının altında kaldığg görülmektedir. Enflasyon dikkate alınarak bir artış yapılmış mıdır? diye bakıldığında 2017 yılı enflasyonunun \%11,92 olduğu dikkate alındığında cari transferlerin 2018 için \%19,3 artırılması ile enflasyonun üzerinde artış yapıldığı, dolayısıyla bu artışın gerçek artış olarak kabul edildiği söylenmelidir.

Tablo 3. 2017-2018 Y1lları Cari Transfer Harcamalarının Türleri ve Büyüklükleri

\begin{tabular}{|c|c|c|c|c|c|}
\hline \multirow{2}{*}{ (Milyon TL) } & \multicolumn{2}{|c|}{ Gerçekleşen } & \multirow{2}{*}{$\begin{array}{l}\text { Artış } \\
\text { Oranı }\end{array}$} & \multicolumn{2}{|c|}{ Bütçe İçindeki Payları } \\
\hline & 2017 & 2018 & & 2017 & 2018 \\
\hline Cari Transferler & 270.924 & 323.099 & 19,3 & 39,9 & 38,9 \\
\hline a) Görev Zararları & 7.371 & 7.406 & $\mathbf{0 , 5}$ & 1,1 & 0,9 \\
\hline KİT Görev Zararları & 3.420 & 2.207 & $-35,5$ & 0,5 & 0,3 \\
\hline Halk Bankası & 1.099 & 1.362 & 23,9 & 0,2 & 0,2 \\
\hline Ziraat Bankası & 2.107 & 2.319 & 10,6 & 0,3 & 0,3 \\
\hline Diğer Görev Zararları & 745 & 1.517 & 103,5 & 0,1 & 0,1 \\
\hline b) Hazine Yardımları & 143.525 & 161.034 & 12,2 & 21,2 & 19,4 \\
\hline SGK'ya Hazine Yardımları & 4.317 & 4.985 & 15,5 & 0,6 & 0,6 \\
\hline - İșsizlik Sigorta Fonu & 3.895 & 4.625 & 18,7 & 0,6 & 0,6 \\
\hline -Sandıklara 5 Puan Prim Desteği & 422 & 359 & $-14,9$ & 0,1 & 0,1 \\
\hline Sağlık, Emeklilik ve Sosyal Yardım Giderleri & 132.466 & 148.388 & 12,2 & 19,5 & 17,9 \\
\hline - Devlet Sosyal Güvenlik Katkısı & 51.767 & 57.560 & 11,2 & 7,6 & 6,9 \\
\hline - Faturalı Ödemeler & 9.621 & 31.467 & 227,1 & 1,4 & 3,8 \\
\hline - Ek Karşılıklar & 2.266 & 2.493 & 10,0 & 0,3 & 0,3 \\
\hline - Emeklilere Ek Ödeme & 8.717 & 9.914 & 13,7 & 1,3 & 1,2 \\
\hline - İşveren Sigorta Primi 5 Puan İndirimi & 27.741 & 20.280 & $-26,9$ & 4,1 & 2,4 \\
\hline - Sosyal Güvenlik Açık Finansmanı & 24.609 & 17.697 & $-28,1$ & 3,6 & 2,1 \\
\hline - Sosyal Güvenliği Olmayanların Sağ.Prim. & 7.744 & 8.973 & 15,8 & 1,1 & 1,2 \\
\hline Mahalli İdarelere Hazine Yardımları & 1.514 & 1.740 & 15,2 & 0,2 & 0,2 \\
\hline -Belediyelere Yardım (Denkleştirme Ödeneği) & 566 & 726 & 28,3 & 0,1 & 0,1 \\
\hline -İl Özel İdareleri (Köy Hiz. Pers. Ücret Öd. & 948 & 1.013 & 6,8 & 0,1 & 0,1 \\
\hline Diğer Hazine Yardımları & 5.227 & 5.920 & $\mathbf{1 3 , 3}$ & $\mathbf{0 , 8}$ & 0,7 \\
\hline -DFİF (İhracat Desteği) & 2.194 & 2.742 & 25,0 & 0,3 & 0,3 \\
\hline - Diğer & 3.033 & 3.177 & 4,7 & 0,4 & 0,4 \\
\hline c) Kar Amacı Gütmeyen Kur. Yapılan Trans. & 3.401 & 3.475 & 2,2 & 0,5 & 0,4 \\
\hline Siyasi Partilere Yardım & 235 & 821 & 249,4 & 0,0 & 0,1 \\
\hline Diğer & 3.166 & 2.653 & $-16,2$ & 0,5 & 0,3 \\
\hline d) Hane Halkına Yapılan Transferler & 6.279 & 7.263 & 15,7 & $\mathbf{0 , 9}$ & $\mathbf{0 , 9}$ \\
\hline *Burslar ve Harçlıklar & 3.621 & 4.403 & 21,6 & 0,5 & 0,5 \\
\hline *Eğitim Amaçlı Diğer Transferler & 1.379 & 1.247 & $-9,5$ & 0,2 & 0,2 \\
\hline *Sağlık Amaçlı Transferler & 211 & 349 & 65,4 & 0,0 & 0,0 \\
\hline *Yiyecek Amaçlı Transferler & 990 & 1.151 & 16,3 & 0,1 & 0,1 \\
\hline *Barınma Amaçlı Transferler & 79 & 112 & 41,7 & 0,0 & 0,0 \\
\hline e) Tarımsal Destekleme Ödemeleri & 12.722 & 14.552 & 14,4 & 1,9 & 1,7 \\
\hline *Alan Bazlı Tarımsal Destekler & 2.635 & 3.544 & 35,0 & 0,4 & 0,4 \\
\hline *Fark Ödemesi Destekleme Hizmetleri & 3.888 & 3.622 & $-6,8$ & 0,6 & 0,4 \\
\hline *Hayvancilık Destekleme Hizmetleri & 3.848 & 3.831 & $-0,4$ & 0,6 & 0,5 \\
\hline *Kırsal Kalkınma Amaçlı Tarımsal Destekler & 795 & 1.397 & 75,7 & 0,1 & 0,2 \\
\hline *Tarım Sigortası Destekleme Hizmetleri & 860 & 1.060 & 23,2 & 0,1 & 0,1 \\
\hline *Telafi Edici Öd. İlişkin Tarımsal Destekler & 191 & 200 & 4,7 & 0,0 & 0,0 \\
\hline *Diğer Tarımsal Amaçlı Destekler & 503 & 893 & 77,5 & 0,1 & 0,1 \\
\hline f) Hane Halkına Yapılan Diğer Transferler & 10.173 & 16.237 & 60,0 & 1,5 & 1,9 \\
\hline *Ekonomi Bakanlığı Teşvik Ödemeleri & 758 & 799 & 5,4 & 0,1 & 0,1 \\
\hline *Turizm Enerji Teşvik Ödemeleri & 469 & 1.159 & 147,0 & 0,1 & 0,1 \\
\hline *KOSGEB (Kobi Desteği) & 1.559 & 1.808 & 16,0 & 0,2 & 0,2 \\
\hline *Tabii Afetten Zarar Gören Çiftçilere Yardım & 0 & 0 & 0 & 0,0 & 0,0 \\
\hline *Bireysel Emeklilik Devlet Katkısı & 3.259 & 3.553 & 9,1 & 0,5 & 0,4 \\
\hline *Diğer & 4.129 & 8.916 & 116,0 & 0,6 & 1,1 \\
\hline g) Sosyal Amaçlı Transferler & 12.226 & 13.781 & 12,7 & 1,8 & 1,7 \\
\hline *SHÇEK Yardımları & 6.336 & 6.871 & 8,4 & 0,9 & 0,8 \\
\hline *2022 Kanun Aylık Ödemeleri & 5.283 & 6.270 & 18,8 & 0,8 & 0,8 \\
\hline *Diğer Sosyal Amaçlı Transferler & 607 & 639 & 5,3 & 0,1 & 0,1 \\
\hline h) Yurtdıșına Yapılan Transferler & 2.633 & 3.238 & 23,1 & 0,4 & 0,4 \\
\hline *Kıbris & 315 & 150 & $-52,4$ & 0,0 & 0,0 \\
\hline *Uluslararası Kuruluşlara Katılım Payı & 1.477 & 1.902 & 28,7 & 0,2 & 0,2 \\
\hline *Diğer & 841 & 1.185 & 41,0 & 0,1 & 0,2 \\
\hline
\end{tabular}

22017 yılı merkezi yönetim giderleri 678.269.193 TL iken 2018 y1lı giderleri 830.449.520 TL olarak gerçekleşmiştir. 
ÇETINKAYA, Özhan ve ASLANTAŞ, Mehmet Fatih - Merkezi Yönetim Cari Transfer Harcamalarının Mali Büyüklüğünün Değerlendirilmesi

\begin{tabular}{|l|c|c|c|c|c|}
\hline i) Gelirden Ayrılan Paylar & $\mathbf{7 2 . 5 9 4}$ & $\mathbf{9 6 . 1 0 9}$ & $\mathbf{3 2 , 4}$ & $\mathbf{1 0 , 7}$ & $\mathbf{1 1 , 6}$ \\
\hline Mahalli İdare Payları & $\mathbf{6 0 . 7 0 4}$ & $\mathbf{7 2 . 4 8 4}$ & $\mathbf{1 9 , 4}$ & $\mathbf{8 , 9}$ & $\mathbf{8 , 7}$ \\
\hline -İl Özel İdarelerine & 2.667 & 3.135 & 17,5 & 0,4 & 0,4 \\
\hline -Büyükşehir Belediyelerine & 26.292 & 31.959 & 21,5 & 3,9 & 3,9 \\
\hline -Büyükşehir İlçe Belediyelerine & 23.809 & 28.041 & 17,7 & 3,5 & 3,4 \\
\hline -Diğer Belediyelere & 7.936 & 9.347 & 17,7 & 1,2 & 1,1 \\
\hline Fon Payları & $\mathbf{1 1 . 5 5 8}$ & $\mathbf{2 2 . 9 9 5}$ & $\mathbf{9 9 , 0}$ & $\mathbf{1 , 7}$ & $\mathbf{2 , 8}$ \\
\hline -SSDF & 5.721 & 15.340 & 176,0 & 0,8 & 1,9 \\
\hline -SYDTF & 5.680 & 7.468 & 31,5 & 0,8 & 0,9 \\
\hline -Diğer Fon Payları & 156 & 186 & 19,2 & 0,0 & 0,0 \\
\hline Gelirden Ayrlan Diğer Paylar & $\mathbf{3 3 3}$ & $\mathbf{6 2 8}$ & $\mathbf{8 8 , 5}$ & $\mathbf{0 , 0}$ & $\mathbf{0 , 1}$ \\
\hline -Toplu Konut İdaresine Aktarılan & 103 & 105 & 1,9 & 0,0 & 0,0 \\
\hline -Diğer paylar & 230 & 523 & 127,4 & 0,0 & 0,0 \\
\hline
\end{tabular}

Kaynak: https://www.muhasebat.gov.tr/content/genel-yonetim-mali-istatistik-detayi?tabId=1\&pageId=2

Tablo 3'deki verilerin analizi yapıldığında, cari transfer harcamalarının bütçe içindeki payının yaklaşı \%39 ile önemli bir düzeyde olduğu, "sağlık/emeklilik/yardım giderleri" nin de yaklaşık \%19'luk pay ile dikkat çektiğidir. Yıl bazında ana harcama türlerinin artışlarına bakıldığında ise hane halkına yapılan diğer transferler (\%60 artış), yurt dışına yapılan transferler $(\% 23,1$ artış), mahalli idarelere ve fonlara yapılan transferler $(\% 32,4)$ dikkat çekmektedir. Bu görüntünün yanında ana başlıkların bazılarında çok düşük artış gözükürken o ana başlığın altındaki bazı alt kalemlerde ise önemli artı̧̧lar dikkat çekmektedir. Örneğin "Görev Zararları" ana kalemi \%0,5 oranı ile yok denecek bir oranda artarken bu kalemin altındaki "diğer görev zararları" altkaleminde \%103,5 oranındaki artış dikkat çekmektedir. Bu zarar KİT'ler ve iki banka zararı dışında yer alan "Üretici Birliklerine", "Tarım Kredi Kooperatiflerine", "Döner Sermayeli İsletmelere" ve "Diğer Teşekküllere" aittir. "Hazine Yardımları" kaleminde ana artı̧ oranı \%12,2 olurken alt kalemde yer alan sağlık kapsamındaki "faturalı ödemeler" kalemi \%227,1 oranında artmıştır. "Kar amacı gütmeyen kurumlara yapılan transferler" sadece \%2,2 oranında artarken bu ana kalemin altında yer alan "siyasi partilere yapılan yardım" kalemi ise $\% 249,4$ oranında artış göstermiştir. "Hane halkına yapılan transferler" \%15,7 oranında artarken sağlık amaçlı olanlar \%65,4 oranında, barınma amaçlı yapılanlar \%41,4 oranında artmıştır. Tarımsal destekleme ödemeleri \%14,4 oranında artarken bu ana kalemin içinde yer alan "Kırsal kalkınma amaçlı tarımsal destekler" \% 75,7 oranında, diğer tarımsal amaçlı destekler \%77,5 oranında artmıştır. "Hane halkına yapılan transferler" dikkat çekecek düzeyde $\% 60$ oranında artmıştır. Bu kalemin içindeki "turizm enerji teşvik ödemeleri" \%147 oranında artmıştır. Diğer hane halkına yapılan ödemeler de \%116 oranında artmıştır. Merkezi yönetim vergi gelirlerinden ayrılıp mahalli idarelere dağıtılan pay gelirleri ise \%32,4 oranında artmıştır. Merkezi yönetim bütçesinin artış oranından fazla artış gözüken bu kalem içinde \%99 oranındaki artış ile fonlara (SSDF ve SYDTF) ayrılan kısım ile diğer idarelere ayrılan pay da gözüken \%127,4 oran da dikkat çekmektedir.

\section{CARİ TRANSFER HARCAMALARININ SIYYASI, ÍKTISADİ VE MALİ AÇIDAN DEĞERLENDÍRILLMESİ}

Kamu harcamalarının maliye politikası aracı olma yönü dikkate alındığında çalışmanın konusunu oluşturan cari transfer harcamalarının cari yıl içinde kullanıma sunulan, faydası bir yıl içinde tüketilen ve karşılığı olmayan harcama niteliklerinden dolayı ekonomiye olan etkileri cari yıl itibariyle kendini gösterebilmektedir. Cari yıl içinde gerçekleşen bu harcamaların reel olarak artış göstermesi çarpan etkisi ile büyümeyi tetiklemesi, enflasyonu da artış yönlü harekete geçirmesi beklenebilecek bir durumdur. Neticede harcama artış1 ile ekonomiye para enjekte edilmektedir. Kamunun gerçekleştirdiği cari yıl giderlerindeki artış anlık göstergeleri yükselterek enflasyona neden olabilecektir. Enflasyonist baskının azaltılması ve uzun dönemli arz imkânlarının artırılması için ekonomik transfer harcamaların artırılması sosyal transfer harcamaların azaltılması (Tokatlığlu ve Selen, 2018:225) gerekli bir politikadır. Cari transfer harcamalarının ekonomik büyüme üzerindeki etkisi ise kaynak tahsisinin yönüne bağlı olacaktır. Yapılan harcamanın yapıldığg yere, kuruluşa ve sektöre göre iyi bir koordinasyon altında kaynak tahsisi politikaları ile gerçekleştirilmesi durumunda ekonomik büyümeye olumlu etkisi olacaktır (Tokatlığlu ve Selen, 2018:394). Yine cari transferlerin yapıldığı yerin durumu da enflasyona etkisini değiştirebilecektir.

Çalışmanın ele aldığı dönem olan 2006-2018 döneminin değerlendirmesine bakıldığında; cari transfer harcamaları her yıl enflasyonun üzerinde artsa da yıllık enflasyonun büyük değişiklikler göstermediği, özellikle 2006 yılından 2017 yılına kadar \%8 ile \%10 arasında bir enflasyon oranı seyri yaşandığ 1 görülmektedir. Bu görüntüye göre diğer kamu harcamalarının, döviz ve faizlerin etkisiz olduğu varsayıldığında, cari transfer harcamalarının artışının enflasyonu önemli bir yönde değişikliğe yöneltmediği söylenebilir. Ancak bu söylem denildiği gibi diğer harcamaların dikkate alınmadığ 
durumda söylenebilir. Diğer harcamaların (yatırım ve diğer transfer harcamaları) döviz ve faizin dikkate alınması durumunda enflasyonun durumu değişiklik gösterebilir. Büyüme rakamlarına bakıldığında ise her yıl ekonominin büyüdüğü görülmektedir. Ancak 2008 krizi sonrasındaki 2009 yılındaki küçülme $(-\% 4,7)$ ile cari transfer harcamalarındaki önemli artış $(\% 30,7)$ dikkat çekmektedir. Bu durum krizin etkilerinin giderilmesi olarak yorumlanabilir. Bu yıl cari transferlerin önemli artışlar yaşanan kalemlerine bakıldığında bu harcamaların çoğunlukla hazine yardımları, görev zararları ve mahalli idarelere yapıldığı görülmektedir. Çalışmanın ele aldığı diğer dönem olarak 2018 yılı verilerine iktisadi ve mali açıdan bakıldığında bu dönemde cari transfer harcamalarının artışının $(\% 19,30)$ enflasyon oranının $(\% 20,30)$ altında kaldığ $(\% 7,4)$ göre yarı yarıya düştüğü $(\% 3,8)$ görülmektedir.

\section{SONUÇ}

Kamu maliyesinde bütçe içinde yer alan harcamaların yapısı ve bunların sınıflandırılması harcama politikalarının belirlenmesinde politika yapıcılarına önemli faydalar sağlamaktadır. Kamu harcamalarının ekonomik sınıflandırmasında yapılan harcamanın etkisinin zaman yönüyle değerlemesi içinde cari harcamaların ve transfer harcamalarının (sermaye teşkili için yapılanları hariç) cari yıla, yatııım harcamalarının ise gelecek yıllara etkisinin olacağı bilinen bir gerçektir. Cari ve transfer kavramlarının birlikte kullanılarak oluşturulan "cari transfer harcamalarının" kavramsal açıklamasının yapılmasını ve merkezi yönetim bütçesi içindeki yerlerini analiz eden bu çalışmada bazı hususlar ortaya çıkmıştır. Bunlar;

1. Cari transfer harcaması kavramı aslında 1940'lı yılların öncesinde de bütçe anlayışı içinde var olan fakat kullanım şekli olarak günümüzdeki gibi bütçe şematiği ve harcama sınıflandırması içinde gösterilmeyen bir kavramdır. 2006 yılında Türkiye'de performans bütçe sistemi ile bütçe hazırlama ve harcama tasnifi şekil değiştirmiş̧ir. Harcamaların "analitik bütçe sınıflandırması" ile tasnifine geçilmesiyle ve "cari transfer harcaması" kavramının kullanılması ile yıllık yapılacak transferleri görmek imkanı ortaya çıkmıştır. Transfer harcamalarının diğer kısmı ise sermaye teşkili oluşturmak amacıyla bir yıldan fazla yapılanlar oluşturmaktadır. Bu şekildeki harcama tasnifi ile yönetimde bulunan yöneticilere bilgi akışının daha yerinde yapılması söz konusu olurken, aynı zamanda çözüm bekleyen sorunlar için doğru değerlendirmeler yapma imkanı da sağlanmış olmaktadır.

2. Cari transfer harcamaları merkezi yönetim bütçesi içinde 2006-2018 dönemi itibariyle önemli yere sahip harcamalar olup 2017 ve 2018 yıllarında da bütçedeki payı yaklaşık \%39 gibi bir oran ile gerçekleşmiştir. 2018 yılı bütçe giderlerinin yaklaşık 830 milyar TL olduğu dikkate alındığında 323 milyar TL harcama bu alana yapılmıştır. Cari transfer harcamalarının en önemli kalemini yaklaşık 150 milyar TL ile (\%18) "sağlık, emeklilik ve sosyal yardım giderleri" oluşturmuştur. Bu rakamlara bakılarak, harcamaların özellikle sosyal güvenlik ayağının (devlet sosyal güvenlik katkısı, işveren sigorta primi 5 puan indirimi, sosyal güvenlik açık finansmanı, işsizlik sigorta fonuna yardım) önemli düzeyde olduğunu, sağlı konusunda da (faturalı ödemeler, sosyal güvenliği olmayanların sağlık primi ödemeleri) dikkat çeken düzeyde harcama yapıldığını, kısacası kanaatimizce sosyal devlet anlayışının yerine getirilmesine çalışıldığı şeklinde yorumlamak mümkündür.

3. Cari transfer harcamalarının 2006 sonrasındaki gelişiminin enflasyon ve büyüme rakamları ile etkileşimine bakıldığında bu harcamaların bütçe içindeki payları her zaman enflasyon oranının üstünde olmuştur. 2008 y1lı kriz yılı ve 2009 yılının da krizin etkisinin devam ettiği yıl olarak dişarıda bırakıldığında büyüme ortalaması \%6,5 olmuştur. Bu görüntüye göre döviz kurları ve faiz oranlarının etkileşimde dışarıda bırakıldığı durumda cari transfer harcamalarındaki artışların enflasyonu artış yönünde etkilemediği, büyüme oranlarına olumlu yönde katkı sağladığı şeklinde (çalışmanın boyutu kapsamında düşünüldüğünde) bir yorum yapmak mümkündür.

4. Makro ekonomik açıdan enflasyon oranının, döviz kurlarının ve işsizlik oranının arttığı ve seçimlerin yapıldığı bir yıl olarak 2018 yılı verilerine bakıldığında cari transfer harcamalarının kümülatif olarak 2017 yılına göre \%1 oranında azaldığı görülmektedir. Seçim yılı olmasından dolayı geniş yönlü bakıldığında harcamaların artacağ 1 şeklinde bir düşünce ilk etapta akla gelse de tam tersi olarak azalma ile sonuçlanması bu durumun Türkiye siyasi yaşamının geleneksel davranış şeklinin dışında bir hareket olarak yorumlanmasına neden olabilir. Ancak yukarıda da değinildiği üzere kümülatif rakamların içine bakıldığında görev zararları, sağlıkla ilgili fatura ödemeleri, hane halkına yapılan transferler, SSDF, tarımsal desteklerdeki artışlara bakıldığında ise bu durumu siyasi davranış şekli olarak görmekte mümkün sosyal devlet anlayışının bir gereği olarak da yorumlamak mümkündür. 


\section{KAYNAKÇA}

BATIREL, Ömer Faruk (1979), Kamu Maliyesi Teorisine Giriş, İstanbul İITTİA Vakfı Yayını, İstanbul.

DUVERGER, Maurice (1955), Âmme Maliyesi (Çev. İsmail Hakkı Ülkmen), Ankara Üniversitesi Maliye Enstitüsü Yayınları, Ankara.

EDIZDOĞAN, Nihat, ÇETINKAYA, Özhan ve GÜMÜŞ, Erhan (2018), Kamu Maliyesi, Ekin Kitabevi, Bursa, 9.Bask1.

ERGINAY, Akif (1981), Kamu Maliyesi, Turhan Kitabevi, Ankara, 9.Bask1.

FALAY, Nihat (1987), Program Bütçe ve Sıfır Esaslı Bütçe Sistemi, İstanbul Üniversitesi Yayını, İstanbul.

FEYZİŎLLU, Bedi Necmeddin (1965), Nazari, Tatbiki, Mukayeseli BÜTÇE, Filiz Kitabevi, İstanbul, 5. Bask1.

GÜRSOY, Bedri (1975), Kamusal Maliye, Sevinç Matbaası, Ankara, C.1, 3. Bask1.

SAYAR, Nihad S. (1954), Amme Maliyesi, Bütçe Prensipleri ve Tatbikatı, Sermet Matbaası, İstanbul, 3. Bask1.

SUSAM, Nazan (2016), Kamu Maliyesi, Beta Yayınları, İstanbul, 2. Bask1.

TOKATLIOĞLU, Mircan ve SELEN, Ufuk (2019), Maliye Politikası, Ekin Yayınevi, 2. Baskı.

http://www.bumko.gov.tr/Eklenti/11265,01-2018-10-8taslak-rehber-aciklamalar2019-2021pdf.pdf?0 (Erişim Tarihi: 03.03.2019).

https://www.muhasebat.gov.tr/content/genel-yonetim-mali-istatistik-detayi?tabId=1\&pageId=2 (Erişim Tarihi: 03.03.2019).

https://www.tuik.gov.tr (Erişim Tarihi: 03.03.2019). 